\title{
THE USE OF MARKET ORIENTATION AS AN EFFECTIVE APPROACH IN WINNING AND SUSTAINING MARKET
}

\author{
Asmai Ishak \\ Fakultas Ekonomi Universitas Islam Indonesia \\ Email: ishaka@fe.uii.ac.id
}

\begin{abstract}
When Asia becomes an integrated market, it means two things for companies operating in it. Firstly, they will have much bigger market, but secondly they will have many new competitors to win the market. The question is, especially for Indonesian companies, are they ready to compete in such more global market? This simple question arises from the reality that most of Indonesian companies are not able to compete with foreign ones. The main reason for this incompetence is that many Indonesian managers tend to ignore customers' needs, and presume that the market will absorb whatever they produce. In current business environment, information technology enables consumers to be well informed, and to select what they want. Only satisfying customer is not enough in today's business environment. This paper discusses the importance of the adoption of market orientation for Indonesian companies to face the environmental changes resulting from Asian as an integrated market.
\end{abstract}

Keywords: market orientation, integrated market, competition

\section{INTRODUCTION}

When Asia becomes an integrated market, it means two things for companies operating in it. Firstly, they will have much bigger market, but secondly they will have many new competitors to win the market. The question is, especially for Indonesian companies, are they ready to compete in such more global market? This simple question arises from the reality that most of Indonesian companies are not able to compete with foreign ones. In the fruit industry, for instance, many supermarkets or department stores prefer providing imported fruits either from Thailand, China, Australia, or America than the local ones. Similarly, garment products from China nearly cover most department stores.

The main reason for this incompetence is that many Indonesian companies do not consider what customers' needs in their policy. They presume that the market will absorb whatever they produce. In fact, this belief is not applicable anymore in current business environment, because information technology enables consumers to be well informed, and to select what they want. Only satisfying customer is not enough in today's business environment. Evidence indicates that many satisfied customers switch to the competitors' brand (Noviani, 2004a). This illustrates that satisfied customers would not always make them loyal. Piercy (2002) asserts that customer's satisfaction and customer's loyalty are different. Satisfaction refers to customer's attitude -how s/he feels about a company or a product, while loyalty refers to the customer's behavior -her or his tendency to buy the same product more than once.

The above explanation demonstrates that making customers loyal to our product or retaining customers is not an easy task. It needs a political willingness and 
genuine commitment not only from the top management but also from the rest of the company. This opinion bases from the belief that customer loyalty could only be realized if the company sees marketing as a strategy and tactic but also as the culture of the company. Such view will lead everyone within the company, from the top to the lower level, to be responsible in satisfying and delighting the customers. This paper discusses the importance of the adoption of market orientation for Indonesian companies to face the environmental changes resulting from Asian as an integrated market.

\section{THE REALITY OF CUSTOMER SER- VICE IN INDONESIA}

Many Indonesian companies develop customer service program or even establish special department to handle customer complain to create customer satisfaction. However, the implementation of the program often creates more dissatisfaction than satisfaction. For example, Sholeh a passenger of Lion Air felt hurt when its departures (from Surabaya to Jakarta and From Jakarta to Surabaya) were delayed for 45 and 90 minutes. He finally sued the Lion company for compensation of Rp.200.800.000,- not only because the delay ruined his business in Jakarta and Surabaya, but also because he was too disappointed with the response of the Lion staff when he complained the delay (Bakri and Fitriyah, 2004).

The above example becomes more interesting because it is not only a matter of customer satisfaction but also relates to the legal protection of customers. It seems impossible for Sholeh to win his charge in the court, because the air transport regulation reveals that the air companies are not responsible for any lost resulting from cancellation and/or delay of the departure, and late of the arrival. This regulation was adopted from Dutch law, and there is no any revision up to now. Inadequate legal protection for customers does not only happen in the air transport industry, but also in other industries such as consumer and industrial product industries.

In addition, many companies create call centers to facilitate and to encourage customers to communicate their complains. However, most of these call centers cannot solve the customer's problem much. The main problem is accessing the phone number that is always busy. Noviani (2004b) reveals that customers have to be patient. They have be ready to redial the number many times because it always engages. When they have already connected, they will head answering machine that will guide them to the needed section. However, if they are unfortunate, they have to wait for the person needed is online, and there is a possibility when they are waiting, the line is disconnected without any clear reason. This situation can make customers more dissatisfied, and lead to a negative perception of the company.

Of course not all call centers are terrible. Unilever Indonesia, for instance, try to pick up the customers' complains and queries through Suara Keluhan Konsumen (SKU). It does not use machine to answer any calls, because it is presumed to be inhuman. Marcelina J. Gunawan, the Consumer Advisory Service Manager, asserts that the SKU program can solve $80-90 \%$ the customer problems directly, while the rests need further process at most five days ( $\mathrm{Pa}-$ lupi, 2004).

In the real life, not all of dissatisfied consumers complain to the company. Many of them just do not repurchase the product when they are unhappy. Poor product performance is not the only source of dissatisfaction. There are many factors that make consumers switch to the competitors' product. Noviani (2004b) reveals some reasons why consumers leave the company. 
The main reason (stated by $69 \%$ of respondents) is poor service. Only small portion of respondents (14\%) switch the brand because of poor product performance. These findings are consistent with the findings of Piercy (2002). Piercy shows that consumer switch to the competitor's brand because of poor service $(43 \%)$, high price $(30 \%)$, poor response to the consumer's complaints, and better service from competitors (10\%).

The above explanations indicate that while most of Indonesian companies have realized the importance of customer satisfaction, only few of them implement supported programs correctly. Companies must be concerned to the dissatisfied customers. Many of those dissatisfied customers not only switch to the competitor's product, but they also tend to tell their bad experience to others. In general, the dissatisfied customers will tell their dissatisfaction to 5 10 of their friends. This contradicts with satisfied customers who only tell their satisfaction or good experience to 2 of their friends (Noviani, 2004).

\section{CUSTOMER SATISFACTION CUSTOMER LOYALTY}

AND

High tension of competition makes companies pay attention more to their customers. They hardly try to satisfy the customers by fulfilling the customers' need. They believe that by fulfilling the need, the customers will satisfy and become loyal. Loyal customers will repurchase the product, become good references for the potential customers, and will lead to the increase in market share and profit of the company. This view seems so straightforward. However, in reality, the view is still questionable, whether we are as the customers or as the businessmen.

As the customer, will you buy same brand of car, if you have more than two cars? Similarly, if you open your wardrobe, will all of your clothes have same brand?
You will answer "no". Does this indicate that you dissatisfy with certain brand of car or clothe? The answer must be "no" too. You bought different brand of cars, because you use each car for different purpose. Likewise, you bought different brand of your clothes, because you want a variation or there was special offer from certain brand at the time. These phenomena imply that satisfied customers do not always repurchase the same brand, however dissatisfied customers will definitely never buy the brand anymore.

In addition, if you are a businessman, how much do you spend your marketing expenses for acquiring new customers, and how do you spend for retaining the existing ones? Which expenses are bigger? You will answer that you spend more on acquiring the new customer than retaining the old ones. This is not only because obtaining new customers is more expensive than maintaining the old ones, but also because you pay attention more on the new customers than the old ones. This fact is very common in the business world management. Evident indicates that even many companies implement customer relationship management in their business strategy, only few of them allocate their marketing expenses more on customer retention program, while the others spend more on finding new customers (Mazur, 2000).

The above facts demonstrate that creating loyal customers is not an easy task and straightforward. It is a complex and challenging task that needs clear political willingness and commitment not only from marketing people and top management but also from everyone within the organization. This opinion is based on the belief that companies can only build loyal customers when they not only perceive marketing as a strategy and tactic, but also as organizational culture. By implementing such belief enables the members of the organization to realize 
that satisfying customers becomes responsibility of everyone within organization from the top to bottom levels.

The conventional view stating that satisfied customers will be loyal is a simplification of a complex issue. However, there is an importance purpose behind this simplification that is customer retention, which can generate potential profit. Empirical evidence demonstrates that customer retention expenses are much cheaper than the expenses of acquiring the new ones (Mazur, 1996). At the same time, another empirical finding reveals that loyal customers spend their money four times more than unloyal ones (Summers, 1993). These two realities show us that the bigger the retained customers in a company are, the higher profit obtained by the company will be. This is because the retained customers can reduce the marketing expenses and increase the sale volume at the same time. In other words, loyal customers can increase the marketing productivity of the company. Summers (1993) discover that the rate of return on marketing investment of old customers is seven times more than the rate of return of new customers. Additionally, marketing managers can use the customer retention program to measure, evaluate, and enhance the customer services that should be provided for the customers, based on their inputs. This can minimize customers to switch to the competitors' brand, be- cause as mentioned in the previous section that customers switch to the competitor's brand not only because of poor product performance but also due to poor customer services and unprofessional staff of the company.

Even companies can provide some potential benefits, but to realize those benefits is not an easy task. Its complexity is as the results of the high competition and the dynamic of customer preference and choice. As explained earlier that the dissatisfied customers will definitely switch to competitor's product. It does not mean that satisfied customers will not go for the competitors. There is still possibility for the satisfied customer to choose another brand whether because of the attractiveness of special offer, or just for variation. This is a warning for marketing managers to carefully understand the meaning of customer satisfaction and customer loyalty.

Customer satisfaction and customer loyalty are two different things. Piercy (2002) explains the different between the two in simple way. Satisfaction is an attitude depicting how customers feel toward company, product, or brand, while loyalty is a behavior describing how often the customers buy certain product or brand. Based on this difference, Piercy then identify four different groups of customers: 


\section{Customer Satisfaction Vs. Customer Loyalty \\ Customer Loyalty}

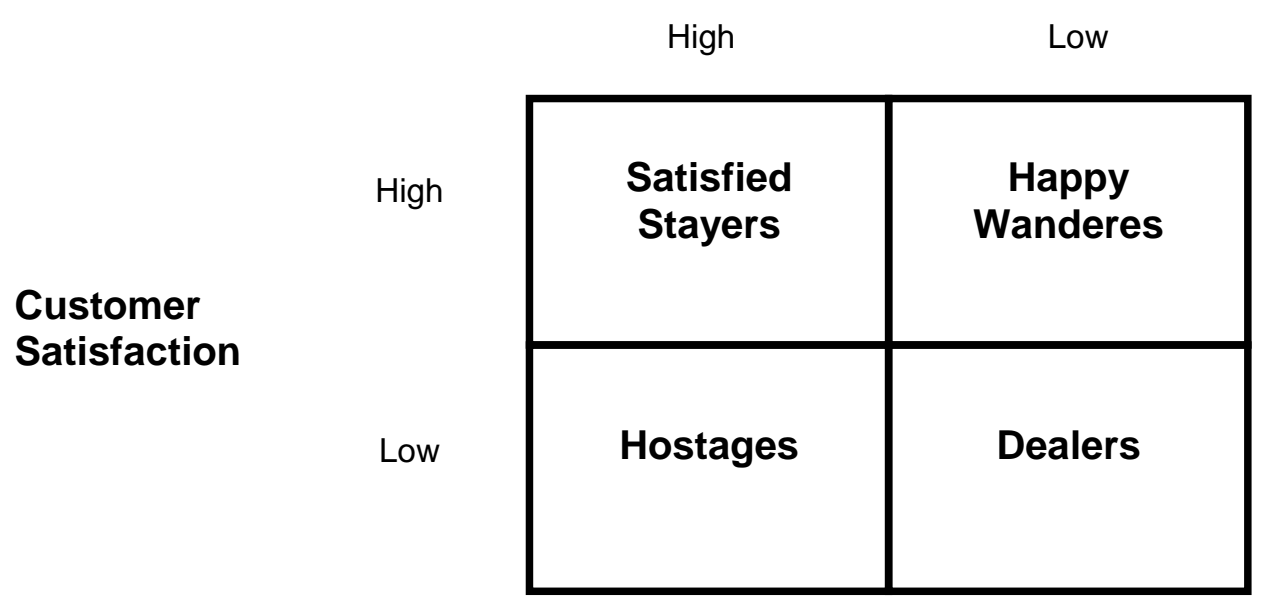

Source: Piercy (2002) page 29

Satisfied Stayers are a group of customers who are very satisfied with certain company, product, or brand, and hence they are very loyal the company, product, or brand. The company can make big profit from this group of customers. As asserted by conventional view, these customers will buy the product at the premium price, and are uninfluenced by competitor's offerings. Marketing managers often make incorrect conclusion because they are unable to differentiate between satisfied stayers and happy wanderers.

Happy wanderers are group of customers who are very satisfied with certain company, product, or brand, but have low loyalty. In other words, even though these customers are satisfied with the product or brand, they still prefer to buy competitor's product because they just want to try something new or because they are interested in special offerings from competitors. This situation is not only happened in consumer market but is also occurred in industrial market, especially when there is a change in the personnel of purchasing division or change in company policy as a whole. This group of customers always gives good assessment when they complete the survey of customer satisfaction, but they themselves are uncertain whether they will rebuy the product in the future. They do not have any emotional relationship to repeatedly buy the product or brand which have already satisfied them.

Hostages are group of customers who are loyal to certain company, product, or brand, even though they are not too satisfied with the product or brand. Many reasons why they tie up to certain product or brand. Firstly, they do not have any choices, like customer of electricity (PLN) and water (PDAM) or customers of McDonald restaurant who cannot order tea bottle of "Sosro" because it is not available. Secondly, they will get cost of switching, economically or psychologically when they change to another brand, for instance, Customers of Simpati (simcard provider) will not easily switch to 
Mentari (another simcard provider), because switching to another provider means change the number of their mobile phone, which can generate problems. Thirdly they do not want to change to another product or brand because tie up with the incentives attached to it, such as frequent flyer, shopping card, and the like. Finally, this group of customers still uses the product or brand because they are lazy to switch to another product or brand. Hostages will be loyal customers, at least for time being, even though they are not too satisfied with the current company, product, or brand.

Dealers are group of customers who are dissatisfied with certain company, product or brand, and switch to another company, product, or brand frequently. These customers are often interested in lower price offerings, and always try to bargain for their benefits.

The above classification of customers describes a clear picture that not all satisfied customers would make repeat purchases, while customers who are not too satisfied could be loyal customers. This indicates that to build customer loyalty is not enough by only considering or measuring the customers' attitude toward the brand. If we do so, it could lead us to incorrect conclusion by assuming happy wanderers (satisfied customers but low loyalty) as satisfied stayers (satisfied and loyal customers). Consequently, the marketing investment could not generate enough return. Considering non-attitudinal factors could do building customer loyalty. Many factors can make customers loyal to certain product or brand, such as experienced by the hostages.

In conclusion, even tough customer satisfaction cannot be used as the predictor of customer loyalty; dissatisfaction is the main indicator for the customer defection. Therefore, marketing managers must look for and better understand why some of their customers switch to the competitors, and why the others stay loyal. They should not simplify the assumptions relating to the customer satisfaction and customer loyalty. Such understanding is important for developing an effective decision of marketing investments, especially relating to such programs as customer satisfaction, relationship marketing, and customer loyalty.

\section{MARKETING CONCEPT, MARKET ORIENTATION, AND ORGANIZA- TIONAL PERFORMANCE.}

Marketing concept has become popular in business since early 60s. Evidence indicated that both large and medium manufacturing firms, to a large extent, adopt the marketing concept (Hise, 1965; McNamara, 1972). Marketing practitioners and academicians believe that marketing concept is a powerful and viable idea influencing management philosophy and thought. They also assert that marketing concept contributes to the improvement of the organization and management of marketing activities. The concept posits that the key to organization's profitability is not current sales volume, but long term customer satisfaction (Drucker, 1954). Supporting this view, Levitt (1960) reveals that customer needs must be the central focus of the organization's objective. These expressions of marketing concept indicate that top management must put the customer interests in the top priorities of the organization. Its product should be tailored and modified in response to the changing customer needs. Profit is not the objective; it is the reward for creating satisfied customers.

Responding the radical changes in business environment in the 80s, (McKenna, 1991)restates the importance of customer satisfaction and marketing concept. $\mathrm{He}$ claims that marketing is not a function, it is away of doing business. Webster Jr. (1992, 1997) suggests re-definition of the marketing role in this new business environment. 
He asserts that marketing has three different dimensions i.e., marketing as culture, marketing as strategy, and marketing as tactic, which could obviously operates in three distinct levels of strategy: corporate, business/SBU, and functional/operating levels. He further explains that each marketing dimension could function in at each level of strategy. The emphasis accorded the separate dimensions of marketing varies with the level of strategy and the level within the hierarchy of the organization.

Market orientation is a framework that details the operational components of the marketing concept. Before 90s, this framework got little attention from marketing academicians. However, the seminal works of (Kohli and Jaworski, 1990; Narver and Slater, 1990)have made market orientation become a new focus of research in marketing. These two studies have become the cornerstones of current research in this area, providing the conceptual foundation of a plethora subsequent research such as, (Avlontis and Gounaris, 1997; Cadogan, Sundqvist, Salminen, and Puumalainen, 2002; Pelham and Wilson, 1996; Váquez, Santos, and Álvarez, 2001; Wood, Bhuian, and Kiecker, 2000)

Kohli and Jaworsky (1990), using interviews with 62 managers in 47 organizations, develop three pillars of the marketing concept into precise aspects of what they call a "market orientation". These pillars are market information generation, dissemination of the information to the whole parts of the organization, and responsiveness to generated and disseminated market intelligence. Kohli and Jaworky reveal that market intelligence is the first stage in market orientation. It focuses not only collecting information of current customer needs and preferences, but also future needs and related factors which affect these needs. Intelligence dissemination refers to the need to communicate, disseminate, and even sell the market intelligence within organization. This indicates that responsibility for satisfying customer needs does not solely lie with a marketing department. All functional departments need to be aware of, and act upon, satisfying the customer needs. Responsiveness refers to the ability of the organization to respond generated and disseminated information. It includes two different activities: response design that is the development of plans, based on the information generated; and response implementation that is the execution of the plans.

On the contrary with Kohli and Jaworsky (1990), Narver and Slater (1990) believe that market orientation is specific form of organizational culture which encourage the emergence of the necessary behaviors for creating value. Based on a review of conceptual literature and an empirical study, they conclude that market orientation comprises three main behaviors: customer orientation, competitor orientation, and interfunctional coordination. Customer orientation is the understanding of an organization toward its target customers to enable it to create superior value continuously. It does not mean that the organization must understand the entire value chain of its customers as it is today, but also as it will evolve over time subject to internal and market dynamics. Competitor orientation refers to the understanding of an organization toward its current and potential competitors in terms of their short-term weaknesses and strengths, long-term capabilities, and strategies. It involves the analysis of current and potential competitors through which the organization could understand how the competitors satisfy their current and potential customers. Interfunctional coordination refers to the coordinated utilization of organization resources in creating superior value for the target customers. To be effective, it requires an alignment of the functional areas' incentives and the creation of interfunc- 
tional dependency so that each area perceives its own advantage in cooperating closely with the others.

Using the conceptual constructs, which they developed, Jaworski and Kohli (1993) and Slater and Narver (1994) investigated the influence of market orientation on the performance among US companies. They found that market orientation has positive effect on the organizational performance, regardless of the environment in which the organizations operate. Supporting this finding, Avlontis and Gounaris (1997) discover that industrial and consumer goods companies adopting market orientation have better performance than companies with other orientations. This better performance is the result of the companies' understanding of their customers, and their ability to adapt the product offered to the customers' needs.

Market orientation is not only applicable for big companies, but also relevant for small companies or even for non-profit organizations. Pelham and Wilson (1996), for example, uncover that small companies responding hostile environment by implementing market orientation gain better longterm performance than companies emphasizing on cost control system and price-cutting. They believe that the market orientation offers the small companies a strong source of competitive advantage and performance viability. Meanwhile, Drummond, Ensor, Laing, and Richardson (2000) and Wood et.al. (2000) demonstrate that the adoption of market orientation enables public servants, such as policemen, doctors, and nurses to provide and deliver better services.

In conclusion, implementing market orientation is prevalent for any organizations to survive and grow in challenge and changing environment. This orientation makes the members of the organizations to focus not only on their customers but also on the move of their competitors. It encourages people within organizations to be creative in producing and delivering products to satisfy their customers better than the competitors. Finally, market orientation makes them aware that everyone within organizations, not only marketing people, is responsible for satisfying customers.

\section{ANTECEDENTS OF MARKET ORI- ENTATION}

Previous studies of market orientation indicate that the strength of the relationship between market orientation and business' performance is moderated by the market environment such as market turbulence, competitive intensity, and technological change (Diamantopoulos and Hart, 1993; Jaworski and Kohli, 1993; Slater and Narver, 1994). The influence of environments on internal organizations has long been recognized in both industrial organization and organization studies (White and Hammermesh, 1981). Industrial organizations scholars believe that industry structures determine the strategy selection of organizations (Porter, 1981). Similarly, an early research in organization studies demonstrate that variety in the environments especially changes in the market and technologies are reflected in the organization forms (Burns and Stalker, 1961). Organizations working under stable environments tend to employ a mechanistic form with centralization, and well-defined chain of commands and communication. On the contrary, Organizations operating in changing environments tend to use an organic form characterized by ambiguous roles, decentralization, and lateral communication. Managers working under such an environment could face greater uncertainty and need greater information processing requirements than managers working in a simple environment (Dess and Beard, 1984).

Consistent with industrial organization and organization studies above, we could expect that market turbulence, com- 
petitive intensity, and technological change would affect the level of a business' market orientation. Davis, Morris, and Allen (1991) found that the perceived environmental turbulence is positively associated with the firm market orientation due to the firm's desire to reduce uncertainty and due to the effectiveness market segmentation efforts in such an environment. Similarly, Pelham and Wilson (1996) discovered that organizations operating in highly competitive markets may place more emphasis on market oriented activities and behavior, than on cost control system, to gain better competitive positions.

In addition to environmental aspects, internal organization factors also affect the level of the business' market orientation. Implementing marketing concept or strategic marketing planning was not an easy task. McDonald (1996) identified two common barriers in the implementation of marketing concept. These include cultural and cognitive barriers.

Leppard and McDonald (1991) asserted that an organization is not simply a conglomeration of people and resources. It embodied a set of values and assumptions, which generated organizational culture and climate. Organizational culture could be the major strength of an organization when it fit the strategies. However it could also be the main weakness when it prevented organizations from meeting competitive threats or from adapting to environmental changes. Understanding the organizational culture provides managers an unfolding context of inertia, and facilitated the execution of the changes (Martin, 1993). This perspective is based on the premise that organizational changes cannot happen unless people or members of the organization change (Schneider, Brief, and Guzzo, 1996). A market orientation is not a set of process and activities, but is a fundamental part of organization's culture. Every members of the organization must understand that the whole purpose of the organization is to create superior value for customers (Farrel, 2000). To execute the market orientation successfully, therefore, an organization must promote managers' empowerment, encourage openness and commitment to the organization, and advocate a collaborative climate and a true concern for providing customer satisfaction (Leppard and McDonald, 1991). Top management of the organization, as cultural carrier, plays a critical role in moulding these organizational values. The involvement of top management in fostering market orientation could generate middle managers involvement and facilitate interdepartmental communication and coordination and eliminate interdepartmental conflicts (Morgan and Piercy, 1998). In the changing business environments, top management cannot detect and respond to the weekly or even to the day-to-day operational changes. Such environments compel the top management to delegate their strategic decision-making and responsibilities to middle managers who are closer to the business reality. They, therefore, should empower their middle managers by allowing them to fix problems at their own level instead of leaving the problems to their superiors and waiting for top-down judgment (Barlett and Ghoshal, 1995). In this way, speed decision-making in response to any environmental changes will be facilitated and political behavior among the managers will be minimized (Bourgeois III and Eisenhardt, 1988). Involving middle managers would end up to a strong sense of psychological ownership and commitment of the middle managers to the organization goals (Denison and Mishra, 1995).

Lacks of marketing skills inhibit marketing manager in promoting market concept within organizations (Denison and McDonald, 1995). This may be the result of Problems of understanding of the managers towards marketing analytical tools. Such problems could be related to the complexity 
of the tools themselves or their application (McDonald, 1992). McDonald (1992) further suggested that both academicians and practicing managers must understand not only the analytical techniques themselves but also the nature of interrelationship among them. This suggestion arose for two reasons. Firstly, misunderstanding of the techniques led to their being misused. Secondly, there was no one technique on its own that could solve the complexity of marketing problems. He believed that some inputs could be used in some models/techniques and outputs of one model could be used as inputs to others. This integration of some models would of course raise another dimension of complexity. However, the availability of computer-based expert systems could overcome human weaknesses in dealing with complexity. Chan and Dandurand (1998) stated that analytical techniques or marketing tools help the managers to scrutinize the business environments, to make strategic and tactical decisions, and to communicate with their superior and other functional managers. Marketing managers can, then, frame the information they have as strategic issues and direct their superior attention to those issues (Dutton and Ashford, 1993).

In conclusion, many factors influence the execution of market orientation. While external business environments affect the level of the implementation of market orientation, internal business environments determine the success of the implementation market orientation. Appropriate culture and analytical competence of managers could facilitate organizations to minimize turbulence effects of external business environments.

\section{CONCLUSION}

The above discussions indicate that adopting market orientation is prevalent to get better performance, especially for those organizations working under changing environments. Many empirical evidences indicate that organizations adopting market orientation gain better performance than their competitors which do not. These signals should encourage Indonesian managers to implement market orientation in managing their organizations to win market competitions. However, executing market orientation is not straightforward. It needs proper culture and analytical competence of managers. Without the existence of the two, the market orientation might not likely generate the intended results.

The organizational culture must promote managers empowerment, encourage openness and commitment to the organization, and advocate a collaborative climate and a true concern for providing customer satisfaction. Such culture not only makes market orientation grow but also encourage the emergence of organizational learning, that is the development of new knowledge or insights that have the potential to influence behavior. These adaptability traits promote norms and beliefs to interact positively with environmental changes, and to incorporate them into the current strategy of the organization. The traits facilitate the organization with the capacity to prioritize its customer satisfaction and to be open to new ideas. However, the existence of market orientation and organizational learning would not directly generate better performance unless managers of the organization have good analytical and technical competencies. Organizational learning in conjunction with analytical and technical competencies could enhance the innovation capacity, which in turn increases product and service innovations within organization (Hurley and Hult, 1998). Market orientation does not influence organizational performance directly. Instead, it affects the performance through product innovation (Baker and Sinkula, 1999). 


\section{REFERENCES}

Avlontis, G. J. and S. P. Gounaris (1997), "Marketing Orientation and Company Performance: Industrial Vs. Consumer Goods Companies," Industrial Marketing Management, 26: 385 - 402.

Baker, W. and J. M. Sinkula (1999), "Learning Orientation, Market Orientation, and Innovation: Integrating and Extending Models of Organizational Performance," Journal of Market Focused Management, 4: 295 - 308.

Bakri, K. B. and N. Fitriyah (2004), "Konsumen Menguji Hukum Kolonial," in Gatra Vol. X.

Barlett, C. A. and S. Ghoshal (1995), "Changing the Role of Top Management: Beyond Systems to People," Harvard Business Review (May/Jun): 132 - 42.

Bourgeois III, L. J. and K. M. Eisenhardt (1988), "Strategic Decision Processes in High Velocity Environments: Four Cases in the Microcomputer Industry," Management Science, 34 (7): 816 - 35.

Burns, T. and G. M. Stalker (1961), Management of Innovation. London: Tavistock.

Cadogan, J.W., S. Sundqvist, R.T. Salminen, and K. Puumalainen (2002), "Market-Oriented Behavior: Comparing Service with Product Exporters," European Journal of Marketing, 36 (9/10): 1076 - 102.

Chan, A. K. K. and L. Dandurand (1998), "A Structural Analysis of Technology Usage in Marketing Planning: Chinese Managers," International Journal of Management, 15 (1): 35 - 44.

Davis, D., M. Morris, and J. Allen (1991), "Perceived Environmental Turbulence and Its Effect on Selected Entrepreneurship and Organizational Characteristics in Industrial Firms," Journal of the Academy of Marketing Science, 19 (Winter): 43 - 91.

Denison, D. R. and A. K. Mishra (1995), "Toward a Theory of Organizational Culture and Effectiveness," Organizational Science, 6 (2): 204 - 23.

Denison, T. and M. McDonald (1995), "The Role of Marketing Past, Present and Future," Journal of Marketing Practice: Applied Marketing Science, 1 (1): 54-76.

Dess, G. G. and D. W. Beard (1984), "Dimensions of Organizational Task Environments," Administrative Science Quarterly, 25: 52 - 73.

Diamantopoulos, A. and S. Hart (1993), "Linking Market Orientation and Company Performance: Preliminary Evidence on Kohli and Jaworski's Framework," Journal of Strategic Marketing, 1 (2): 93 - 121.

Drucker, P. F. (1954), The Practice of Management. New York: Harper \& Row.

Drummond, G., J. Ensor, A. Laing, and N. Richardson. (2000), "Market Orientation Applied to Police Service Strategies," The International Journal of Public Sector Management, 13 (17): 571 - 89.

Dutton, J. E. and S. J. Ashford (1993), "Selling Issues to Top Management," Academy of Management Review, 18 (3): 397 - 428. 
Farrel, M. A. (2000), "Developing a Market-Oriented Learning Organisation," Australian Journal of Management, 25 (2): 201 - 22.

Hise, R. T. (1965), "Have Manufacturing Firm Adopted the Marketing Concept?," Journal of Marketing, 29 (Jul.): 9-12.

Hurley, R. F. and A. T. M. Hult (1998), "Innovation, Market Orientation, and Organizational Learning: An Integration and Empirical Examination," Journal of Marketing, 62 (3): 42 - 54 .

Jaworski, B. J. and A. J. Kohli (1993), "Market Orientation: Antecedents and consequences," Journal of Marketing, 57 (3/Jul): 53-70.

Kohli, A. K. and B. J. Jaworski (1990), "Market Orientation: The Construct, Research Propositions, and Managerial Implications," Journal of Marketing, 54 (April): 1 - 18.

Leppard, J. W. and M. H. B. McDonald (1991), "Marketing Planning Corporate Culture: A Conseptual Framework which Examines Management Attitudes in the Context of Marketing Planning," Journal of Marketing Management, 7: 213 - 35.

Levitt, T. (1960), "Marketing Myopia," Harvard Business Review (Jul/Aug): 45-56.

Martin, R. (1993), "Changing the Mind of the Corporation," Harvard Business Review (Nov/Dec): 81 - 94.

Mazur, Laura (1996), "Accountability," in Marketing Business. , (2000), "Booking Skills for Future," in Marketing Business.

McDonald, M. H. B. (1992), "Strategic Marketing: A State-of-the-Art Review," Marketing Intelligence \& Planning, 10 (4): 4-22.

(1996), "Strategic Marketing Planning: Theory, Practice and Research Agenda," Journal of Marketing Management, 12: 5-27.

McKenna, Regis (1991), "Marketing Is Everything," Harvard Business Review (Jan-Feb): 65-79.

McNamara, C. P. (1972), "The Present Status of The Marketing Concept," Journal of Marketing, 36 (Jan): 50-57.

Morgan, N. A. and N. F. Piercy (1998), "Interactions between Marketing and Quality at the SBU Level: Influences and Outcomes," Journal of the Academy of Marketing Science, 26 (3): 190 - 208.

Narver, J. C. and S. F. Slater (1990), "The Effect of A Market Orientation on Business Profitability," Journal of Marketing, 54 (October): 20 - 35.

Noviani, Lisa (2004a), "Investigasi ala Mystery Shopping," in Marketing Vol. IV. , (2004b), "Sulitnya Menelpon Operator Seluler ...," in Marketing Vol. IV.

Palupi, D. H. (2004), "Nanyi Sunyi Suara Konsumen Unilever," in Mix Vol. 06. 
Pelham, A. M. and D. T. Wilson (1996), "A Longitudinal Study of the Impact of Market Structure, Firm Structure, Strategy, and Market Orientation Culture on Dimensions of Small-Firm Performance," Journal of the Academy of Marketing Science, 24 (1): $27-43$.

Piercy, N. F. (2002), Market-Led Strategic Change (3rd ed.). Oxford: ButterworthHeinemann.

Porter, M. (1981), "The Contribution of Industrial Organization to Strategic Management," Academy of Management Review, 6 (4): 600 - 20.

Schneider, B., A. P. Brief, and R. A. Guzzo (1996), "Creating a Climate and Culture for Sustainable Organizational Change," Organizational Dynamics (Spring): 7 - 18.

Slater, S. F. and J.C. Narver (1994), "Does Competitive Environment Moderate the Market Orientation-Performance Relationship?," Jornal of Marketing, 58 (January): 46 - 55.

Summers, Diane (1993), "Rewards for the Loyal Shoppers," in Financial Times.

Váquez, R., M. L. Santos, and L. I. Álvarez (2001), "Market Orientation, Innovation and Competitive Strategies in Industrial Firms," Journal of Strategic Marketing, 9: 69 90.

Webster Jr., F. E. (1992), "The Changing Role of Marketing in the Corporation," Journal of Marketing, 56 (Oct.): 1-17.

(1997), "The Future Role of Marketing in the Organization," in Reflections on the Futures of Marketing, Donald R. Lehmann and Katherine E. Jocz, Eds. Cambridge, MA: Marketing Science Institute.

White, B. and R. G. Hammermesh (1981), "Toward a model of Business Unit Performance: An Integrative Approach," Academy of Management Review, 6 (2): 213 - 23.

Wood, V. R., S. Bhuian, and P. Kiecker (2000), "Market Orientation and Organizational Performance in Not-for-Profit Hospitals," Journal of Business Research, 48: 213 - 26. 